
ЗАБЕЗПЕЧЕННЯ ДІЯЛЬНОСТІ МЕДИЧНИХ УСТАНОВ

\author{
Matsyk O.V., \\ postgraduate student at the department of \\ management, public administration and personnel, \\ Western Ukrainian National University
}

\title{
MODERNIZATION OF INFORMATION AND COMMUNICATION SUPPORT OF MEDICAL INSTITUTIONS
}

Постановка проблеми. Сфера охорони здоров'я тісно пов'язана 3 накопиченням і обробленням значних обсягів інформації. Обсяги інформації, якими оперують медичні установи, безперервно збільшуються. Систематично зростає кількість звернень населення до закладів охорони здоров'я. Тому серед найважливіших проблем організації функціонування установ охорони здоров'я сьогодні слід, у першу чергу, назвати їх інформатизацію. Неможливо забезпечити реформування системи охорони здоров'я, домогтися високої якості надання медичної допомоги, прозорості й оперативності управління без впровадження сучасних методів зберігання, оброблення та передавання інформації. 3 метою забезпечення належної якості медичної допомоги існує потреба в накопиченні й аналізі даних впродовж тривалого періоду, застосуванні медичних інформаційних систем.

Впровадження сучасних інформаційних технологій в діяльність медичних установ $є$ важливим фрактором підвищення якості медичного обслуговування. Без застосування сучасної комп'ютерного та програмного забезпечення практично неможливо забезпечити повноцінний моніторинг стану здоров'я населення, фрормувати потоки пацієнтів і керувати ними та ресурсними потоками, здійснювати зворотній зв'язок і оперативний контроль за дотриманням нормативів та стандартів лікування, забезпечувати перехід від постатейного бюджетування до сучасних методів економічного управління в сфері охорони здоров'я. В усіх цих випадках доводиться здійснювати великі обсяги роботи, яка відносно легко автоматизується.

Науковий імператив дослідження посилюється необхідністю цифровізації економіки України та іï̈ секторів, діджиталізацією всіх управлінських процесів [8], адже важливо не лише втілювати зміни, але і комунікувати з громадянами, акцентувати увагу на потенціалі, інформувати про плани та результати роботи з використанням новітніх інформаційних платформ.

Аналіз останніх досліджень і публікацій. Проблеми впровадження сучасних інформаційних технологій в діяльність медичних установ у своїх працях досліджували О. В. Балуєва, М.М.Білинська, Ю.В.Вороненко [6], А. В. Владзимирський [1], Р. Р. Ларіна [5], О. П. Минцер, В. П. Мегедь, Я. Ф. Радиш [2-3], С. А. Яренко [9] та ін. Віддаючи належне теоретичній і практичній значущості наукового доробку зазначених учених, слід звернути увагу на те, що проблема модернізації інформаційно-комунікативного забезпечення діяльності медичних установ недостатньо глибоко досліджена у вітчизняній наукові літературі та потребує подальшого вивчення.

Постановка завдання. Метою статті $\epsilon$ обґрунтування необхідності модернізації інформаційно-комунікативного забезпечення діяльності медичних установ України для підвищення якості надання медичної допомоги та медичних послуг.

Виклад основного матеріалу дослідження. Важливим елементом організаційного забезпечення діяльності медичних установ виступають інформаційно-комунікативні зв'язки між всіма структурними підрозділами організації та їх працівниками. Тому резерви модернізації процесу координації діяльності медичних установ лежать в площині інформаційно-комунікативного забезпечення їх діяльності.

\footnotetext{
" Науковий керівник: Желюк Т.Л. - д-р екон. наук, професор.
} 
Інформаційний ресурси - це банки даних, бази знань, масиви документів, книг тощо, що є в інформаційних системах внаслідок збору та обробки інформації. Використання інфрормації проходить через інформаційні процеси. Інформаційними процесами (функціями) інформаційних систем є збір, передача, обробка, збереження та надання користувачам необхідних видів інформації. Використання інформації відбувається шляхом використання комунікацій. Інформаційно комунікаційну інфраструктуру інформаційної системи складають технічні засоби, засоби зв'язку (комунікації), мережі інформаційних служб (інформаційні відділи тощо) і місць збереження інформації (архіви, бібліотеки, фонди тощо) [4].

Перспективним напрямком модернізації інформаційно-комунікативного забезпечення медичних установ $€$ запровадження в їх роботу медичних інфрормаційних систем, наприклад, інформаційної системи «Доктор Елекс», яка розроблена для автоматизації роботи медичних закладів незалежно від їхніх розмірів і профрілю [7]. Важливим елементом даної інфрормаційної системи є безпосередня взаємодія та сумісність з сучасним медичним обладнанням. Ця система є також відкритою для стикування в майбутньому зі створюваною експертною системою для прогнозування, оптимізації і контролю лікувального процесу.

Медична інформаційна система «Доктор Елекс» $€$ найпоширенішою в Україні медичною системою, що з 2005 року успішно працює в державних та приватних закладах Києва, Вінниці, Львова, Маріуполя та інших міст (табл. 1). Сьогодні в ній ведуться електронні картки більш ніж 5 млн. пацієнтів [7]. Система забезпечує автоматизацію всіх ключових процесів установи - від ведення електронної історії хвороби до формування управлінської звітності та документації згідно вимог Міністерства охорони здоров'я України.

Вітчизняні державні та приватні медичні установи, які модернізували інформаційнокомунікативне забезпечення своєї діяльності за допомогою медичної інформаційної системи «Доктор Елекс»

\begin{tabular}{|l|l|}
\hline \multicolumn{1}{|c|}{ Державні медичні установи } & \multicolumn{1}{|c|}{ Приватні медичні установи } \\
\hline 1) Національна дитяча клінічна спеціалізована лікарня & 1) медична компанія «INTO-SANA»; \\
«ОХМАТДИТ» (хірургічне відділення); & 2) клініка «Медіком»; \\
2) Державний клінічнии науково-практичний центр & 3) медична компанія «llaуа»; \\
телемедицини МО3 України; & 4) медичний центр «Інго»; \\
3) Центр первинної медико-санітарної допомоги № 1 " & 5) медичний центр Св. Параскеви; \\
Подільського району м. Києва; & 6) група компаній «Мать и Дитя»; \\
4) Львівська міська дитяча клінічна лікарня; & 7) клініка «Неаlthy аnd Нарру»; \\
5) Одеська університетська клініка; & 8) мережа стоматологічних клінік «Пародент»; \\
6) Ладиженське територіальне медичне об’єднання; & 9) міжнародна клініка відновного лікування тощо. \\
7) медичні заклади м. Віннцці в рамках програми & \\
автоматизації на 2011-2015 роки тощо. & \\
\hline
\end{tabular}

Джерело: сформовано автором

Основними функціями медичної інформаційної системи «Доктор Елекс» є: систематизація роботи медичної установи; забезпечення гармонійної співпраці усього персоналу; впровадження контролю за процесом лікування; можливість швидко знаходити потрібну інформацію; підвищення якості обслуговування пацієнтів [7].

Основною перевагою запропонованої медичної інформаційної системи «Доктор Елекс»є те, що вона легко конфігурується відповідно до специфіки діяльності кожної конкретної установи, аби керівництво могло з легкістю поєднувати управлінські та медичні аспекти своєї діяльності. Розширений перелік переваг медичної інформаційної системи «Доктор Елекс» представлений в табл. 2.

Центральним елементом медичної інформаційної системи «Доктор Елекс» є інформаційний супровід лікарських оглядів. Для ефрективного здійснення цієї важливої процедури розроблено інноваційний спосіб введення, зберігання і аналізу результатів оглядів. Класичний підхід до вирішення цієї проблеми вимагає створення для кожного огляду спеціальної таблиці з відповідними полями. Недоліком такого підходу є погана масштабованість даних, він вимагає багато ресурсів для підтримки і аналізу. Іншим підходом є зберігання інформації про огляди у текстовій фрормі. Проте представлені в такому вигляді дані в подальшому практично неможливо аналізувати.

Новизна пропонованого підходу полягає у відокремленні метаданих від даних з результатами конкретних оглядів. Метадані - це шаблон документа про лікарський огляд або будь-якого іншого документу, що зберігається у виді дерева, вузлами якого є елементи документа. Перевагами запропонованого підходу $є$ : швидке та ефективне здійснення оглядів; динамічне створення шаблонів оглядів кінцевими користувачами - лікарями; оптимізація процесу введення інформації про огляд; ефективний доступ до даних для аналізу. При цьому програмне забезпечення системи 
забезпечує зручний облік пацієнтів, формування розкладу роботи медичного персоналу та автоматизацію документообігу.

\section{Переваги медичної інформаційної системи «Доктор Елекс»}

\begin{tabular}{|c|c|}
\hline \multicolumn{2}{|c|}{ Переваги для керівного персоналу } \\
\hline $\begin{array}{l}\text { - оперативне отримання інформації; } \\
\text { - аналіз діяльності установи та підготовка } \\
\text { статистичних звітів; } \\
\text { - контроль за правильністю та повнотою введення } \\
\text { даних обстежень; }\end{array}$ & $\begin{array}{l}\text { - заощадження часу та ресурсів завдяки відмові від } \\
\text { паперового документообігу; } \\
\text { - облік завантаженості працівників та обсягу наданих } \\
\text { послуг; } \\
\text { - регламентування прав доступу; } \\
\text { - моніторинг історії прибутків та витрат; }\end{array}$ \\
\hline \multicolumn{2}{|c|}{ Переваги для лікарського персоналу } \\
\hline $\begin{array}{l}\text { - спрощений пошук інформації про пацієнта; } \\
\text { - швидкий та легкий ввід даних огляду завдяки } \\
\text { унікальній системі деревовидних шаблонів; } \\
\text { - зменшення кількості медичних помилок у у } \\
\text { документах; } \\
\text { - швидке введення даних лабораторних аналізів; }\end{array}$ & $\begin{array}{l}\text { - візуальне виділення інформації у випадку } \\
\text { відхилення від норми; } \\
\text { - робота з діагностичним обладнанням: запис відео } \\
\text { та зображень; } \\
\text { - наявність редактора зображень та відео, } \\
\text { можливість виділення ключових кадрів; } \\
\text { - дотримання регламентованого порядку огляду; }\end{array}$ \\
\hline \multicolumn{2}{|c|}{ Переваги для працівників реєстратури } \\
\hline $\begin{array}{l}\text { - централізоване зберігання інформації; } \\
\text { - швидка та зручна система планування візитів; } \\
\text { - детальна інформація про пацієнта - призначення, } \\
\text { послуги та розрахунки; } \\
\text { - оперативне реагування на телефонні дзвінки; } \\
\text { - контроль за обслуговуванням пацієнтів; }\end{array}$ & $\begin{array}{l}\text { - швидке формування звітів для керівництва; } \\
\text { - зручне налаштування форми відображення } \\
\text { розкладу та його корекції; }\end{array}$ \\
\hline
\end{tabular}

Джерело: складено автором

Програмне забезпечення медичної інформаційної системи «Доктор Елекс» складається 3 модулів, які забезпечують функціонування відповідних автоматизованих робочих місць. Доступними $€$ такі робочі місця: «реєстратура, «лікар», «лабораторія», «адміністрування», «шаблони» [7].

Автоматизоване робоче місце забезпечує для користувача швидкий і інтуїтивний доступ до потрібної функціональності. В майбутньому будуть розроблені також спеціалізовані модулі для великих медичних закладів, наприклад, «фрармацевт», «медсестра відділу», «адміністративний модуль» для керування розміщенням та слідкування за станом пацієнтів стаціонару. Робочі місця забезпечують введення документів різних типів. Доступ до робочих місць і типи документів, з якими вони працюють, визначається адміністратором відповідно до ролі кожного користувача в системі. В цьому полягає динамічність робочих місць - при однаковому розміщенні об'єктів на екрані для медичних працівників різних спеціалізацій показується різна інформація. Нижче детальніше описано кожен модуль.

Модуль «реєстратура» призначений для супроводження процедур приймання пацієнтів, керування розкладом роботи лікарів і обслуговування пацієнтів, ведення усієї немедичної інформації, що стосується пацієнта. Модуль веде також облік здійснених процедур, курсів лікування, історії пацієнтів. Персоналу реєстратури доступні такі функціональні блоки: облік пацієнтів; облік лікарського розкладу; швидкий пошук інформації про пацієнта; облік наданих пацієнту послуг, ведення документів, які напряму не стосуються лікування - інформації про пацієнта.

Модуль «лікар». Лікар є центральною фрігурою у проекті «Доктор Елекс». Робоче місце лікаря полегшує, систематизує і оптимізує роботу 3 хворими. Вся необхідна інформація має бути доступною і зручною у користуванні. Для робочого місця лікаря доступними $є$ опції формування розкладів прийому пацієнтів, оперування з документами вибраного пацієнта і швидкого введення даних огляду. Коли пацієнт приходить на прийом, лікар має можливість переглянути документи, що стосуються цього хворого, створені іншими спеціалістами - аналізи, діагнози, огляди. Також для лікаря створено можливості швидкого і ефективного введення інформації огляду, причому дані 3 медичних апаратів автоматично вставляються в документи оглядів.

Основним завданням модуля «лабораторія» $€$ швидкий і безпомилковий аналіз та введення інформації про лабораторні дослідження. Лабораторію не цікавить особа пацієнта, а лише його аналізи. Для оптимізації процесу вводу результатів аналізів кожен пацієнт отримує спеціальний ідентифікаційний номер. Отримавши аналізи, спеціаліст лабораторії вибирає потрібний тип аналізів, вводить номер пацієнта і заповнює карту аналізів. По завершенню документ зберігається, вводиться номер наступного пацієнта і так далі. Працівник лабораторії має доступ до документів, які він створював протягом дня для внесення можливих корекцій. Зручне та швидке введення інформації, 
перевірка даних в процесі вводу, миттєвий доступ лікаря до введених документів - поширення інформації в клініці - все це робить інформаційну систему «Доктор Елекс» центральною ланкою, яка об'єднує різні спеціалізації медичного закладу.

Модуль «адміністрування». Адміністратор - це працівник медичного закладу, від якого не вимагається медичної підготовки. Його функції - забезпечити роботу інформаційної системи, правильне налаштування робочих місць, керування доступом, управління правами користувачів системи. Також його обов'язком $є$ обслуговування бази даних і регулярний аудит записів про операції, які здійснено користувачами. Аудит є важливим аспектом діяльності лікарні, адже будь-які зміни в медичній інформації, будь-який доступ до інформації мають бути санкціонованими. У випадку вводу неправильної інформації або несанкціонованого доступу до документації потрібно мати можливість швидко та ефективно відслідковувати усі дії користувачів. Виконання саме таких функцій забезпечує робоче місце адміністратора: управління користувачами; управління ролями; управління доступом ролей до документів; налаштування робочих місць працівників лабораторії, реєстратури і лікарів; управління доступом до функціонального наповнення програмного забезпечення; аудит діяльності користувачів. Проста у використанні, гнучка і ефективна система адміністрування дає відповідному персоналу повний контроль над роботою інформаційної системи.

Модуль «шаблони». Шаблони документів є однією з основних частин інформаційної системи. Для їхнього формування створено спеціальне робоче місце. Стандартизація оглядів є важливою складовою діяльності клініки, процедури оглядів розробляються спеціально навченими лікарями, потім затверджуються на консиліумах, оптимізуються і удосконалюються протягом усього часу функціонування медичного закладу. Програмне забезпечення робочого місця розробника шаблонів складається з трьох частин: дерева огляду, деталей вибраного вузла і перегляду результуючого документа.

Важливою компонентою інформаційної системи «Доктор Елекс» $є$ деревовидні шаблони оглядів. Сама ідея розділення даних і метаданих не $є$ новою, вона використовується в сучасних базах даних. Натомість уніфікація можливих елементів документів і представлення логічних зв'язків між ними у виді дерева є новими.

Документи створюються на базі шаблонів. Шаблони і дані документів зберігаються окремо. Для перегляду користувачем генерується спеціальне представлення у форматі HTML. Шаблон визначає зовнішній вид і внутрішнє наповнення документа. Для підтримки старих документів використовується версійність - документ завжди працює на основі версії шаблона, за допомогою якої його було створено.

В інформаційній системі «Доктор Елекс» шаблон огляду представляється у вигляді дерева 3 вузлами різного типу, зокрема: секція (частина документа, яка може повторюватись багато разів); дані (дата, цілочисельні, дробові, стрічкові, нотатка, так/ні); зображення; група вибору кількох елементів; група вибору одного елемента; елемент групи; таблиця; текст; вибір зі словника (словник діагнозів, процедур, установ тощо); стандартні (ім'я пацієнта, його вік, стать, лікар який лікує, та ін.); посилання (елемент попередньо створеного документа).

3 цих елементів легко і швидко формуються складні документи. Дані документів стають потім доступними для аналізу і використання в інших документах.

Інноваційним $є$ підхід до представлення процедури опитування пацієнта у виді дерева. Якщо у пацієнта є якісь проблеми, то ці проблеми деталізуються. Якщо відповідної проблеми немає, то гілки опитування, які відповідають за її деталізацію, просто не показуються. Такий підхід дозволяє гнучко адаптувати процедуру опитування і зробити при потребі деталізацію будь-якого рівня.

Для завантаження стандартних (часто вживаних у медичних документах) даних використовуються елементи типу «стандартні». Це дозволяє суттєво зменшити кількість помилок вводу і прискорити заповнення стандартних полів документа. Також автоматично вставляється дата введення та ім'я і прізвище особи, яка здійснює заповнення документа. Для забезпечення автоматичного підвантажування даних, записаних в попередніх документах, використовується вузол типу «посилання». Він дає можливість вставляти в документ значення вузла іншого документа, попередньо створеного для пацієнта. На базі цього типу вузла генеруються виписки 3 історії хвороби.

Важливим елементом підходу є версійність шаблонів документів. Якщо за шаблоном створено хоча б один документ, його не можна змінювати. Натомість для редагування шаблона створюється нова версія, яка копіюється з попередньої. В результаті всі нові документи створюються згідно 3 новою версією шаблона, а старі документи відображаються і редагуються відповідно до старших шаблонів. Версійність породжує проблему аналізу даних - потрібно знати, який вузол є копією іншого. Для цього в системі введено спеціальні ідентифікатори вузлів - так звані статичні ідентифікатори. Вузли з однаковими статичними ідентифікаторами мають те саме значення. Це дозволяє досліджувати динаміку зміни параметрів пацієнта в часі незалежно від версій документа. Тобто вузли мають значення самі по собі. Якщо в оглядах різних спеціалістів використовуються однакові елементи обстежень, вони будуть мати однакові статичні ідентифікатори. Завдяки цьому 
реалізовано так зване зв'язування документів - заповнення нової інформації документа на основі попередньо створеного документа в історії хвороби пацієнта.

Для підтримки і легкого управління великою кількістю стандартних шаблонів оглядів створено репозиторій шаблонів оглядів. Репозиторій забезпечує виконання таких функцій: збереження поточних шаблонів документів в репозиторій з певною назвою; завантаження шаблонів документів 3 репозиторія; завантаження первинної версії шаблона документа з репозиторія; зберігання поточної версії шаблона документа на місце первинної версії в репозиторії; завантаження шаблона документа з репозиторія.

Такий набір функцій дозволяє легко керувати доступними шаблонами документів і настроювати набір шаблонів під конкретну медичну установу. Наприклад, онкологічній клініці не потрібні гінекологічні огляди, гінекологічній - онкологія. Великим лікарням потрібне і те, й інше. Репозиторій інформаційної системи «Доктор Елекс» - це фактично база знань, яка дозволяє легко і швидко донести потрібну інформацію до цільової аудиторії.

В оглядах можуть використовуватись зображення та числові дані, отримані з діагностичного обладнання. Розроблений інтерфейс забезпечує введення даних різних типів медичної інформації: зображення (рентген чи томографрія); відеозображення (наприклад, результати УзІ); результати лабораторних аналізів.

Інформація з медичних діагностичних пристроїв автоматично потрапляє в елементи огляду. Сумісність зі стандартом DICOM дозволяє фрормувати і зберігати візуальну інформацію в фрорматі, зручному для подальшого аналізу. Стандарт HL7 дає можливість обмінюватись інформацією зі складними діагностичними пристроями з використанням спеціальних протоколів.

Важливим елементом медичного процесу є виписка з історії хвороби пацієнта. Виписка - це підсумковий документ про стан пацієнта, його діагнози і лікування. Виписка фрактично $\epsilon$ узагальненням інформації, попередньо введеної під час оглядів, та інформації з інших документів, що стосуються пацієнта. Виписка сама по собі $€$ документом. У виписках широко застосовуються вузли типу «посилання» на інші документи. За складними правилами, використовуючи результати оглядів, генеруються фррази виписки. Можливість копіювання шаблонів із збереженням логічних зв'язків дає можливість генерувати виписки різними мовами. Мова виписки - природна, коротка, базована на логічному аналізі документів пацієнта [7].

Висновки 3 проведеного дослідження. Запровадження медичної інформаційної системи «Доктор Елекс» в діяльність медичних установ дозволить суттєво підвищити рівень координації діяльності її персоналу. Наше припущення ґрунтується на досвіді впровадження даної системи в окремих медичних закладах України, таких як: центр репродуктології «Інтерсоно»; науковий медикодіагностичний центр «Астар»; медичний центр «Венера»; Міжнародна клініка відновного лікування; Івано-Франківська обласна клінічній лікарня; Львівський обласний кардіологічний центр тощо.

\section{Література}

1. Владзимирський А. В. Телемедицина в системі менеджмента та організації охорони здоров'я : навчальний посібник. Донецьк : ТОВ «Цифрова друкарня», 2012. 468 с.

2. Державна політика у сфері охорони здоров'я : кол. моногр. : у 2 ч. / кол. авт. ; упоряд. профр. Я. Ф. Радиш ; передм. та заг. ред. проф. М. М. Білинської, проф. Я. Ф. Радиша. Київ : НАДУ, 2013. Ч. 1. $396 \mathrm{c}$.

3. Державна політика у сфрері охорони здоров'я : кол. моногр. : у 2 ч. / кол. авт. ; упоряд. проф. Я. Ф. Радиш ; передм. та заг. ред. проф. М. М. Білинської, проф. Я. Ф. Радиша. Київ : НАДУ, 2013. Ч. 2. $484 \mathrm{c}$.

4. Концепція розвитку цифрової економіки та суспільства України на 2018-2020 роки. URL: https://zakon.rada.gov.ua/laws/show/67-2018-\%D1\%80\#Text (дата звернення: 15.06.2020).

5. Ларіна Р.Р., Владзимирський А. В., Балуєва О.В. Державний механізм забезпечення інформатизації системи охорони здоров'я : монографія / за заг. ред. проф. В. В. Дорофієнко. Донецьк : «Вебер», 2008. 252 с.

6. Менеджмент в охороні здоров'я : навчально-методичний посібник / за ред. Ю. В. Вороненка. Київ : НМАПО, 2014. 367 с.

7. Офіційний сайт інформаційної системи «Доктор Елекс». URL: https://doctor.eleks.com/ (дата звернення: 15.06.2020).

8. Цифрова адженда України. URL: https:/ucci.org.ua/uploads/files/58e78ee3c3922.pdf (дата звернення: 15.06.2020).

9. Яремко С. А. Впровадження інформаційних систем в організаційно-управлінські структури медичних закладів. Вісник Хмельницького національного університету. 2015. № 6(207). С. $237-242$. 


\section{References}

1. Vladzymyrskyi, A.V. (2012), Telemedytsyna v systemi menedzhmenta ta orhanizatsii okhorony zdorovia [Telemedicine in management systems and organization of health protection], tutorial, TOV "Tsyfrova drukarnia", Donetsk, Ukraine, 468 p.

2. Radysh, Ya.F. and Bilynska, M.M. (2013), Derzhavna polityka u sferi okhorony zdorovia [State policy in the sphere of health protection], collective monograph, in 2 part, NADU, Kyiv, Ukraine, Part 1, $396 \mathrm{p}$.

3. Radysh, Ya.F. and Bilynska, M.M. (2013), Derzhavna polityka u sferi okhorony zdorovia [State policy in the sphere of health protection], collective monograph, in 2 part, NADU, Kyiv, Ukraine, Part 2, $484 \mathrm{p}$.

4. "Concept for the development of the digital economy and support of Ukraine for 2018-2020", available at: https://zakon.rada.gov.ua/laws/show/67-2018-\%D1\%80\#Text (access date June 15, 2020).

5. Larina, R.R., Vladzymyrskyi, A.V. and Baluieva, O.V. (2008), Derzhavnyi mekhanizm zabezpechennia informatyzatsii systemy okhorony zdorovia [State mechanism of securing informatization of health protection systems], monograph, "Veber", Donetsk, Ukraine, 252 p.

6. Voronenko, Yu.V. (Ed.) (2014), Menedzhment $v$ okhoroni zdorovia [Management in health protection], NMAPO, Kyiv, Ukraine, 367 p.

7. "Official site of the information system "Doctor Eleks"”, available at: https://doctor.eleks.com/ (access date June 15, 2020).

8. "Digital Agenda of Ukraine", available at: https://ucci.org.ua/uploads/files/58e78ee3c3922.pdf (access date June 15, 2020).

9. Yaremko, S.A. (2015), "Introduced information systems in the organization and management structures of medical mortgages", Visnyk Khmelnytskoho natsionalnoho universytetu, no. 6(207), pp. 237242. 